\title{
After Tamerlane: The Global History of Empire since 1405
}

Review Number: 2040

Publish date: Thursday, 5 January, 2017

Author: John Darwin

ISBN: 9780713996678

Date of Publication: 2007

Price: $£ 7.01$

Pages: 592pp.

Publisher: Allen Lane

Publisher url: https://www.penguin.co.uk/books/54403/after-tamerlane/9780141904689/

Place of Publication: London

Reviewer: Anjana Singh

How does one define empire? What are the characteristics of a successful empire? These two questions arise foremost after reading John Darwin's monumental masterpiece After Tamerlane. In nine succinct chapters with informative titles, Darwin encompassed 600 years of global history, supported by illustrations and maps and for those interested, suggestions for further reading. In the preface he considers the economic, political and cultural impact of globalization on history writing and argues that understanding the course, nature, scale and limits of Europe's expansion -the rise of the West- can only be understood when one shifts the lens away from Europe and focuses on Eurasia. This book helped us understand how the world became what it is: globalised. This book, by a leading scholar of colonial and global history has been rightly acclaimed as brilliant, brave and pioneering in challenging Euro-centric global history which in a linear way interprets Europe's 19th-century hegemony as predestined by Columbus and Vasco da Gama's journey into the sea; as if, standing on the shores of Europe in the 1490s, these men were aware that they were setting Europe on an imperial path leading to the ascendancy of the colonial empires of the 18th, 19th and 20th centuries.

John Darwin, in this convincing and fascinating book, basically argues that in world history, empires have been the rule, not the exception. He shows that the Tartar emperor Tamerlane was the last great empirebuilder to rule over both Europe and Asia. After Tamerlane's demise in 1405, a few great empires came into being: the Qing and Ming in present day China, the Vijayanagara and Mughal in India, the Safavid in Iran and the Ottoman in Turkey. These Asian empires co-existed with fragmentary European nation-states until the 19th century when European conquests overtook large parts of Asia and Africa, culminating in exploitative colonial empires. By late 20th century, the last of the colonies were freed and nation-states in many varieties emerged as the new form of polity all over the globe. He is critical of nationalist interpretations of the rise and fall of empires and argues against the exaggerated importance given to Europe. Such an ambitious book, vast in its coverage of both time and space, naturally did not pass by without criticism. One shortfall of the book is that it does not clearly lay out the connections between empire building and violence, a theme we will return to later. However, Darwin does persuade readers into accepting that empires still exist, for example in China, Vietnam, India and United States.

In the ten years since the book was first published, our world has changed dramatically. The year 2016 has delivered striking surprises: Britain's recent vote to leave the European Union, rise of right wing anti- 
immigrant and anti-globalisation sentiments in the United States, nativism, narrow nationalism sweeping across parts of Europe (specially Britain, France, Netherlands and Austria), the rise of neo-Nazis in Germany and overall economic nationalism cross the globe. In 2011, war broke out in Yemen, Libya and Syria and these conflicts continue to create havoc, kill and displace millions of people. In 2014, a right-wing Hindu nationalist party was democratically elected into power in India and NATO ended combat operations in Afghanistan, leaving the country in a state of collapse. At the dawn of the century, these would not have been the developments one anticipated discussing with students at universities while teaching a course on global history or the process and impact of globalization in a course on political, social or economic history. In the face of the surging growth of right-wing political and economic nationalism in Asia, Europe and America, one struggles to contextualise and explain globalisation, its history, social and economic causes, consequences, advantages and disadvantages. The debate between globalization and nationalism is getting brassier. Democracies are electing right-wing narrow nationalists to power and their opinions are reverberating among urban educated middle-class people across the globe.

What then is the relevance of a well-acclaimed popular global history book as After Tamerlane in the present-day scenario? What does this authoritative analysis of global history tell us about lessons learnt and perhaps more importantly lessons lost or forgotten? For one, Euro-Russo-American imperialism is here to stay. Post mid-20th-century decolonization, 'the West's' intervention and destabilizing impact on 'the rest' has become clear, both in Africa and the Middle East - two of the major theatres of the Cold War. So one wonders if empire building continues. And if empire is a matter of power and influence, are empires, of the sort witnessed in the 20th century, on the rise again? If so, what will their characteristics be and how different will they be from the early modern Asian empires and modern colonial European empires? The wars in the Middle East in the last few years, especially in Syria, with the siege and near total destruction of Aleppo, demonstrate the violence unleashed when attempts are made by militant men under the cloak of religion to establish their rule. That empire building is intrinsically connected with violence is clear. Millions of anonymous individuals pay a heavy price when multiple parties form alliances to establish control over land, without caring the least about the people who inhabit the lands. It is to be hoped that the Middle East will stabilise with time, as Africa is beginningto do, but even this path will not be violence-free. Civil wars and genocides will take place, of the kind we have seen in Sudan and South Sudan. The exact characteristics of empires may vary from region to region, but violence (as etched out in some parts by Darwin in his analysis on slavery) displacement of people and imperial wars, seem to be a permanent feature.

It seems that at some level the ground-breaking critical works of an erudite scholar like John Darwin have been ineffective in countering self-assured Euro-centric teleologies, both among historians and in popular discourse. This history of the globe since 1400 is less the story of the rise of the west and more a story of the resilience of Eurasia to a uniform system. The concept of Europe-led march to 'modernity' has been challenged and both in political and economic spheres 'the rest' appear to be finding their own way forward. While some nations are failing and others come into being, the economic growth that is led by the so called BRICS (Brazil, Russia, India, China and South Africa) seems to be laying out new rules for modernisation and mercantilist driven empire building. The focus has been not on the old school pre-Tamerlane 'Eurasia' but on forging relationships among the post-colonial new kids on the block. This new kind of economic empire building, backed by multi-national corporations and aided by technology, shared past historical experiences, and future ambitions appears to focus on the location and use of resources, rather than the occupation of territory, focusing more on the exploitation of natural resources through trans-national cooperation and the maximising of profits by multinational corporations, often backed by states and presented to the masses as nation-building. Defining and differentiating empire and nation-state is becoming more and more thought-provoking. Economic empires are on the rise. Capitalism of the few and by the few is a threat to all.

The United States is an important case in point. The results of the elections of 2016 can be seen as a clear case of growing economic nationalism. Anti-immigrant and anti-globalization sentiments have been embraced by a crude populism that promises to return to a 'glorious past'. If the past was glorious, then at what cost does one return to this mythical status, do not seem to be questions worthy of an answer among 
the anxious millions who appear easily swayed by an oversimplified narration of ill effects of globalisation. Immigration, the rise of India and China, and competition from these emerging markets were used as an explanation for their hardships: unemployment, dwindling standards of living and rising economic inequality. After the financial crisis of 2008, it has been easy to believe that declining productivity growth and slower income growth for low- and middle-income families were due to globalisation. It has been easy to ignore the evidence that prosperity comes from trade and to trade one needs to produce goods and services and have access to large integrated markets.

With changing times, in the past few years, the relevance of this book has increased manifold. Staying true to his profession, historian Darwin states: '[n]o prediction is safe. Like all previous generations, we face the future with little more than guesswork on which to build our plans' (p. 485). Perhaps the most important lesson to be drawn from this book comes from Darwin's preface - the importance of studying global and nonWestern history (p. xi). It seems that we are now paying the price for ignoring and disregarding multiple and complex narratives of history in our school and university curricula. As 'the West' faces resource crunch and the economies of Asia and Africa are recording a comparatively faster rate of economic growth, it is crucial that neither ignores the importance of allocating resources to studying and writing histories in multiple interpretations, so that we can plan our futures better. Paradoxically, both economic crisis and economic growth are leading to right-wing nationalism across the globe. For now, it is clear that we historians have been unsuccessful in disseminating lessons learnt from our pasts to a broader audience.

\section{Other reviews:}

\section{Guardian}

https://www.theguardian.com/books/2007/may/12/featuresreviews.guardianreview7 [2]

\section{$\mathrm{H}-\mathrm{Net}$}

https://networks.h-net.org/node/20292/reviews/76791/squizzero-darwin-after-tamerlane-global-historyempire-1405 [3]

Telegraph

http://www.telegraph.co.uk/culture/books/3665483/The-struggle-for-supremacy.html [4]

Source URL:https://reviews.history.ac.uk/review/2040

\section{Links}

[1] https://reviews.history.ac.uk/item/163433

[2] https://www.theguardian.com/books/2007/may/12/featuresreviews.guardianreview7

[3] https://networks.h-net.org/node/20292/reviews/76791/squizzero-darwin-after-tamerlane-global-historyempire-1405 [4] http://www.telegraph.co.uk/culture/books/3665483/The-struggle-for-supremacy.html 